\title{
LIBERDADE, CIDADANIA E POLÍTICA DE EMANCIPAÇÃO ESCRAVA
}

\author{
Jefferson Cano*
}

RESUMO: Este artigo analisa o papel político dos fazendeiros campineiros no processo de emancipação escrava. Ele sugere que a ação daqueles senhores de escravos nos anos 70 do século XIX, tentando preservar a força de trabalho escrava, deve ser entendida dentro de um projeto político mais amplo - o projeto liberal, que guiava a construção do Estado imperial.

ABSTRACT: This article analyses the political role of Campinas' planters in the process of the Brazilian slave emancipation. It suggests that the action of those slaveowners in the 1870's, trying to preserve the slave labour force, might be understood within a wider political project - the liberal one, which guided the making of the imperial State.

Palavras-Chave: Liberalismo, Escravidão, Abolição, Liberdade, Cidadania

Keywords: Liberalism, Slavery, Abolition, Liberty, Citizenship

"Sem a população escrava de Atenas, vinte mil atenienses não poderiam deliberar em praça pública todos os dias."

"O perigo da liberdade moderna, é que absorvidos no gozo de nossa independência privada, e na busca de nossos interesses particulares, nós não renunciemos muito facilmente a nosso direito de participar do poder político."

Benjamin Constant. De la liberté des anciens comparée à celle des modernes, 1819

* Doutorando em História Social pela Unicamp.
A instituição da escravidão, respeitadas consideráveis diferenças de tempo e lugar, sempre veio introduzir um nível a mais de complexidade nas relações entre as esferas do público e do privado, tal como as entendemos hoje. Esta complexidade era, por exemplo, o que expressava muito oportunamente o cônsul romano Plínio, o moço, em uma de suas Cartas, ao afirmar que, para o escravo, a casa do senhor era como que uma res publica, onde ele era cidadão (PLINY, 1992, p. 48).

O ilustre missivista retratava no domínio sobre seus escravos como que uma reprodução microcósmica do espaço público, ao mesmo tempo que exem- 
plificava como privadamente eram criados os limites deste espaço; "dentro dos limites de sua casa", os escravos tinham reconhecidos seus direitos sobre o que viessem a possuir, e mesmo lhes era permitido fazer testamentos, que eram tratados como se legalmente firmados: as instruções dos escravos eram cumpridas pelo senhor como se este "agisse sob ordens".

Se, por um lado, a magnanimidade de um senhor podia conferir a seu escravo, privadamente, o reconhecimento de direitos que não lhe dava a lei civil, por outro lado, o ato exclusivamente privado da alforria era capaz de trazer (aí sim legalmente) o escravo para a mesma categoria social de seu exsenhor. Assim, um ex-escravo de um cidadão romano tornava-se, obedecidas algumas condições, também um cidadão, podendo ascender, ao menos perante a lei, até mais que outras categorias de homens nascidos livres, mas não cidadãos (FINLEY, 1989, p. 134; The Institutes of Gaius, 1988).

A correspondência privada de Plínio não seria nada de especialmente esclarecedor para nossos propósitos, a não ser porque, cerca de dezenove séculos mais tarde, em 1866, o exemplo da prática romana de manumissões seria acenado pelo jurista brasileiro Perdigão Malheiro como uma maneira de se extinguir no país a "diversidade de classes, suas rivalidades e odiosidades" (MALHEIRO, 1976, p.143). Desde então, tem sido muito recorrente a lembrança de Perdigão Malheiro sobre as restrições aos libertos e a seus "direitos de cidadania" no Brasil do século XIX (CUNHA, 1985, pp. 62-ss.). Entretanto, afirmações deste tipo sobre a sociedade imperial correm um grande risco de resvalar no anacronismo, desconsiderando-se as especificidades do conceito de cidadania ao qual se referem, tão diferente do que será empregado no século XX, num mundo exclusivo de homens livres, quanto daquele que empregava Plínio entre os séculos I-II da nossa era.
Uma especificidade que vinha expressa, de maneira muito clara, pelo próprio Perdigão Malheiro:

“(...) é Cidadão Brasileiro por nascimento o liberto que no Brasil tenha nascido (...) Mas a lei, atendendo a preconceitos de nossa sociedade, (...) tolhe aos libertos alguns direitos em relação à vida política e pública." (MALHEIRO, 1976, p.141, grifos do autor)

E de fato a legislação acabava excluindo da esfera política a maioria da população — tanto livre quanto escrava. Esta exclusão já foi interpretada como uma contradição inerente à vida política do Império, que tentaria acomodar o direito de uma sociedade escravista à linguagem do liberalismo (CUNHA, 1987, p. 140; CARVALHO, 1987, p.162); assim, o liberalismo no Brasil teria sido sempre "uma flor espúria e frágil” (COSTA, 1975, p. 9), desprovido de seu "conteúdo pleno e concreto" (BOSI, 1992, p. 195), e que se via obrigado a "verdadeiras contorções discursivas" (MALERBA, 1994, p. 140) para acomodar-se à realidade de uma sociedade escravista.

Vista sob outro prisma, porém, quando nos atemos mais à própria "linguagem do liberalismo", parece muito menos tratar-se de uma contradição, do que de uma perfeita consonância entre aquela sociedade e o liberalismo da época que, fosse no Brasil ou na Europa, tinha na própria exclusão a sua pedra fundamental. Dessa maneira, deixamos de limitar o entendimento da sociedade imperial por algumas premissas, que parecem apresentar-se como conclusões; pois tomar como um a priori a incompatibilidade entre a sociedade escravista do Brasil oitocentista e a ideologia liberal significa, em geral, ter por suposto um conceito de liberalismo como uma doutrina que "pleiteava uma horizontalidade entre indivíduos livres e iguais - pressuposto para as relações contratuais de livre mercado" (MALERBA, 1994, p. 34), definição esta perfeitamente de acordo com a auto-representação desta ideologia, mas que peca, 
quando menos, por desconsiderar as experiências históricas, se não boa parte da própria fala liberal.

Estaria muito além das pretensões deste artigo uma discussão pormenorizada da teoria liberal, a começar pelo próprio conceito de liberalismo, que não deixa de levantar inúmeros problemas para aquele que queira dele aproximar-se. Na verdade, se nos ativéssemos rigorosamente aos significados históricos, teríamos dificuldades até mesmo em identificar este conceito na acepção que lhe conferimos hoje. Do ponto de vista meramente etimológico, encontramos antes o uso do adjetivo liberal, e só posteriormente o do substantivo liberalismo, ambos, aparentemente, de uso generalizado primeiro no francês, e daí disseminados para outros idiomas. Segundo nos informa o dicionário Le Grand Robert no verbete "liberal", esta palavra, em sua acepção de "favorável às liberdades individuais, no domínio político", dataria de 1750 , quando utilizada pelo Marquês d'Argenson. Também no dicionário de Littré, editado em 1889, encontramos este mesmo sentido, de "favorável à liberdade civil e política", ainda que datado um pouco menos precisamente, derivando "pelo menos do consulado".

Quanto ao verbete "liberalismo", cuja primeira aparição é datada pelo Robert de 1818, parece ter feito uma peregrinação muito mais lenta pelos vocabulários políticos, visto que ainda não constaria do Novo Diccionário da Lingua Portugueza de Eduardo de Faria, editado no Rio de Janeiro em 1859 - data bem avançada, se considerarmos que a denominação de "liberal" já era então moeda corrente na vida política do Império há décadas. Mas mesmo onde encontramos um eloqüente verbete dedicado à "esta bela palavra liberalismo", como no enciclopédico Grand Diccionnaire Universel du XIX Siècle, de Pierre Larousse, não avançamos além do sentido já identificado em "liberal", ligado à defesa das liberdades civis e políticas, e identificado a um partido:
"Na tribuna, na imprensa e até nas sociedades secretas, ele retomou a luta engajada havia trinta anos entre a Revolução Francesa e o antigo regime" (LAROUSSE, 1873, p. 465)

Luta localizada então na França da restauração bourbônica, contra o "restabelecimento do antigo regime com todas as suas iniqüidades (...) sob a égide da monarquia absoluta". Segundo nos informa este dicionário, o nome de liberais teria sido lançado como uma injúria pelos realistas aos seus adversários da oposição, que prontamente o assumiram e popularizaram, substituindo o de independentes.

Assim, o liberalismo era, adentrando o último quartel do século XIX, identificado à bandeira de Lafayette, não de Adam Smith, pois o lugar deste era em outro verbete do mesmo dicionário, "libreéchange", uma adaptação do inglês "free trade", ao contrário de "liberalisme", palavra autóctone. Mas era aí, nos princípios do "libre-échange", que "se resumem na famosa divisa: laissez faire, laissez passer" (LAROUSSE, 1873, p. 482), que encontrávamos a definição do que chamamos comumente liberalismo econômico.

Por estarem fundamentados no direito natural, os princípios do laissez faire, laissez passer seriam, "num futuro próximo, a lei econômica geral de todos os povos civilizados". Mas apesar desta convicção, mesmo o confiante dicionarista hesitava em endossar as opiniões mais extremadas de um economista como Fréderic Bastiat, aquele que teria levado "resolutamente até ao absurdo as conseqüências excessivas de um princípio verdadeiro, mas absoluto demais". Estas consequiências excessivas surgiam em seu estudo sobre as Harmonias Econômicas, de 1850, que tentava responder a questão sobre até que ponto um governo tem o direito de intervir nas relações do trabalho individual. Da leitura de Bastiat o nosso dicionarista concluía que

"Se (...) chegamos até a negar a existência de interesses coletivos; se uma sociedade política não é senão a justaposição de 
indivíduos gozando, cada um sobre o terreno que ocupa, de plena soberania e plena independência; se (...) a única missão que eles consentem ao poder público é a de manter entre eles a balança igual e de velar pela segurança comum; se o direito de propriedade, com todas as conseqüências que dele decorrem, está além da esfera legislativa, de maneira que a lei não deve intervir senão para consagrá-lo e para fortalecê-lo, e não para regulamentá-lo; se, para dizer tudo em uma palavra, o Estado é apenas uma ficção, e somente o indivíduo uma realidade, então nem há questão, e todos os tratados de comércio entre nações, desde os fenícios até nossos dias, foram usurpações."

Ora, fica claro deste sumário de princípios que, embora o vocabulário da época nos indique uma cesura conceitual entre liberalismo político e liberalismo econômico, em nenhum momento pode-se distinguir claramente estas duas categorias, que teimavam em imbricar-se nos princípios da economia política. Esta tendência à separação e à classificação entre as esferas do cotidiano já foi ressaltada com muita pertinência por E.P. Thompson, ao lembrar que as premissas da economia política "propunham ser possível não só identificar determinadas atividades como 'econômicas', mas também separá-las, como campo especial de estudos, das outras atividades (política, religiosa, legal, 'moral' — como a área das normas e valores era então definida - cultural etc.)" (THOMPSON, 1981, p. 71).

Mas esta tendência à compartimentação não impediria a construção de um projeto de saber (e portanto de poder, lembraria Bacon) abrangente, fosse em um Adam Smith, precedendo sua Riqueza das Nações (1776) de uma Teoria dos Sentimentos Morais (1759), fosse do próprio Bastiat, apontando, através de suas "harmonias", um encadeamento de categorias que cumpriam o percurso da economia à política e do indivíduo ao grupo:

"Indicarei algumas das relações, ou melhor das harmonias da economia política com as outras ciências morais e sociais, lançando um olhar sobre graves assuntos expressos por estas palavras: interesse pessoal, propriedade, comunidade, liberdade, igual- dade, responsabilidade, solidariedade, fraternidade, unidade." (BASTIAT, 1954, p. 160)

Poderíamos ainda precaver-nos contra esta tentação classificatória citando o exemplo de Locke, que atrela a política definitivamente à economia ao lembrar que "o fim maior e principal do fato de os homens se unirem em sociedades políticas e se submeterem a um governo é a conservação de suas propriedades" (LOCKE, 1982, p. 319). Mas não se trata apenas disto, e nem principalmente disto. Pois se podemos extrapolar as falas de nossos personagens, buscando um fio de continuidade entre discursos como o de Locke e o Estado de Natureza, ou Adam Smith, Bastiat e a liberdade de comércio, é por encontrarmos em todos um elemento que nos permite chegar à definição de liberalismo que remete tal conceito a um período anterior à própria palavra, pela identificação de um "núcleo ontológico e metafísico" firmado no individualismo (ARBLASTER, 1985, p. 15).

Neste sentido, elaborada em seus princípios básicos já desde John Locke, a teoria liberal, longe de pressupor uma horizontalidade incondicional entre os indivíduos, não via embaraços em justificar a desigualdade, uma vez que as diferentes condições dos indivíduos com relação à propriedade resultavam de diferentes desempenhos no uso da razão - esta sim, capacidade que igualava originariamente os homens (DAVIS, 1970; FRANCO, 1993). Desta maneira, a própria escravidão, ainda que negação da "liberdade natural", encontrava justificação, legitimando então, por meio da propriedade, da razão e, consequentemente, da própria condição humana, a exclusão de uma parcela dos indivíduos da sociedade civil:

“(...) sendo feitos prisioneiros numa guerra justa, são por direito de natureza submetidos ao domínio absoluto e ao poder arbitrário de seus senhores. Tendo, por assim dizer, perdido a vida, e com ela a liberdade, e os próprios haveres, e sendo, no estado de 
escravidão, incapazes de propriedade, esses homens não podem ser considerados como parte da sociedade civil, cujo fim principal é a conservação da propriedade." (LOCKE, 1982, p. 286)

E mesmo bem mais tarde, quando adentrava o século XIX, a fala liberal ainda distinguia-se perfeitamente dos princípios democráticos que lhe seriam posteriormente acrescentados, principalmente pela pressão de um movimento operário organizado (HOBSBAWM, 1992). Era o que ficava claro em Jeremy Bentham, escrevendo em 1824 sobre o sofisma da "autoridade do número", ao qual "se se quisesse dar valor, caminharíamos direto ao absurdo" (BENTHAM, 1944, p. 60). Nesse mesmo sentido, Benjamin Constant explicava dez anos antes de Bentham, e ainda mais explicitamente, as condições para se exercer os direitos políticos:

"Eu não quero fazer qualquer injustiça à classe trabalhadora. Esta classe não possui menos patriotismo que as outras. Freqüentemente ela está pronta aos sacrifícios mais heróicos, e seu devotamento é tanto mais admirável que ele não é recompensado nem pela fortuna nem pela glória. Mas um, eu creio, é o patriotismo que dá a coragem de morrer por seu país, e outro é o que torna capaz de bem conhecer seus interesses. É preciso, pois, uma condição a mais que o nascimento e a idade prescritos pela lei. Esta condição é o lazer indispensável à aquisição das luzes, à retidão do julgamento. Somente a propriedade assegura este lazer: somente a propriedade torna os homens capazes do exercício dos direitos políticos." (CONSTANT, 1872, p. 252)

Para além das teorias, um olhar sobre a situação política de países como Inglaterra e França demonstra cabalmente que a participação política não se contava entre o patrimônio das populações européias da primeira metade do século XIX. Na verdade, mesmo entre as nações européias, a política inglesa aparecia de maneira algo idealizada, como para o italiano Cavour, que notava em 1848 que se o voto aberto "é compatível com os longos e fortes hábitos do viver livre na Inglaterra, não poderia introduzirse entre nós sem gravíssimos inconvenientes"
(ROMANELLI, 1988, p. 691). Entretanto, apesar destes "fortes hábitos do viver livre" na Inglaterra, o Reform Act de 1832 levaria o eleitorado de cerca de 360.000 para 650.000 numa população de pouco mais de 13 milhões de habitantes, e mesmo após o segundo Reform Act, de 1867, o eleitorado virtualmente dobraria, passando de 1.056.000 para 1.995.000 numa população de mais de 20 milhões (EVANS, 1983a e 1983b; WRIGLEY, 1989).

Quanto à França, a Lei Laîné, de 1817, estipulava a exigência de 30 anos de idade e 300 francos de censo para ser eleitor, e 40 anos de idade e 1000 francos de censo para ser elegível. Só depois da revolução de 1830 o censo seria reduzido a 200 francos para ser eleitor e 500 francos para ser elegível, o que aproximadamente dobrou o eleitorado, para cerca de 200.000 numa população de 32 milhões. Ironicamente, quem defenderia uma maior participação política na França, por meio de eleições indiretas, seriam os ultra-realistas, temerosos de deixar a vida política entregue às mãos das classes médias perpassadas por idéias liberais e anti-monárquicas. Por outro lado, a altamente restritiva Lei Laîné seria vivamente defendida pelos liberais como uma de suas maiores conquistas (JARDIN, 1973). Quanto à defesa das eleições indiretas pelos ultra-realistas, retomava um dispositivo presente na constituição republicana do ano VIII (1799), que estabelecera um sistema de eleições em quatro graus.

Não custa lembrar que este sistema acabou sendo adotado pela Constituição brasileira de 1824, só que apenas em dois graus. Sugestivo da diferença entre os dois sistemas eleitorais, era o comentário do mais famoso comentador da Constituição, o conselheiro José Antônio Pimenta Bueno, ao notar, em 1857, que "cumpre reconhecer, entretanto, que desde que prevalece a eleição direta, a lei eleitoral não deve ser tão ampla ou liberal como é a nossa" (BUENO, 1978, p.193). Para melhor avaliar estas palavras, lembremos que nas eleições de 1872 o elei- 
torado chegou a $10,8 \%$ da população do Império, e parece lícito supor que a participação eleitoral não fosse significativamente menor em períodos anteriores, quando Pimenta Bueno escrevia, por exemplo, e que não o foi até a reforma eleitoral da lei Saraiva, em 1881, esta bem mais restritiva, e justamente ao estabelecer as eleições diretas, sendo que nas eleições de 1886 o eleitorado já teria caído para $0,8 \%$ da população.

Obviamente, números podem ser discutidos em vários sentidos, e, sendo a fraude praticamente a regra no sistema eleitoral do Império, não é nem de longe nossa intenção sugerir que o sistema político brasileiro fosse então mais democrático que outros, provavelmente por dar até aos mortos o direito de voto. Pelo contrário, o que queremos dizer é que não faria sentido discutirmos a política imperial cobrando dela uma característica — democracia — que não se encontrava no horizonte político de qualquer outra monarquia européia. $\mathrm{Ou}$ - o que era ainda pior — que só se vira até então passar do horizonte ao primeiro plano em momentos de crises revolucionárias, como na fase do Terror da Revolução Francesa, quando o sufrágio universal masculino foi introduzido na Constituição de 1793, que logo seria revogada, dois anos mais tarde.

$\mathrm{E}$, com toda a certeza, o sufrágio universal era o ponto em que a França claramente não poderia servir de exemplo para outras monarquias durante todo o século XIX, e não só pelo exemplo do terror da Revolução, mas também porque novamente em 1848 , quando outra vez se instituiu o sufrágio universal, foi ao fim de outra revolução que punha fim a uma monarquia; e também porque era o sufrágio universal que havia referendado o golpe de estado de Louis Bonaparte, sua coroação como Napoleão III, e seu império, cuja queda sob a Comuna de 1870-71 traria à burguesia as mais sombrias lembranças de 1792-93.

Mas não é necessário adiantarmos esta história, pois é claro que os homens que instituíram a ordem imperial no Brasil dos anos 1820 não estavam prevendo os acontecimentos franceses dos anos 40, 50 ou 70; eles estavam, sim, empenhados em construir uma ordem que pudesse oferecer segurança e manter intocadas, tanto as propriedades dos cidadãos quanto as cabeças dos monarcas. Da mesma maneira que os dirigentes da Europa pós-napoleônica empenhavam-se em fazer esquecer os efeitos do vendaval revolucionário, não só redesenhando os mapas, mas também (ou principalmente?) os princípios da representação política remanescentes da Revolução e do Império. E, mais do que apenas um aspecto da "restauração", a onda contra-revolucionária atingia igualmente os países que não tinham o que restaurar por não terem sofrido uma invasão, como a Inglaterra, onde, aliás, talvez até mesmo pelo fato de não ter sofrido uma invasão, a reação conservadora pôde se articular desde muito antes (THOMPSON, 1987).

Quanto à organização do Império brasileiro, desde a convocação da Assembléia em 1823 - quando D. Pedro lembrava aos deputados que as constituições que tentavam seguir o exemplo francês de 1791 e 1793, "a experiência nos tem mostrado que são totalmente teoréticas, e metafísicas, e por isso inexeqüíveis"; ou então quando jurava defender a Constituição "se fosse digna do Brasil e de mim" (Constituições do Brasil, p. 34) — seguia de perto os passos da Charte Constitutionnelle de 1814, da qual Luís XVIII, "voluntariamente e pelo livre exercício de nossa autoridade real" resolveu fazer "concessão e outorga" a seus súditos. Uma carta que apreciava "os efeitos do progresso sempre crescente das luzes", mas que ao mesmo tempo buscava seus princípios nos "monumentos veneráveis dos séculos passados":

"Nós consideramos que, embora toda a autoridade na França residisse na pessoa do rei, (...) nós reconhecemos que o desejo de nossos súditos por uma Carta Constitucional era a expressão de 
uma necessidade real; mas cedendo a este desejo, tomamos todas as precauções para que esta Carta fosse digna de nós e do povo que nos foi confiado para comandar." (DUVERGER, 1957, p. 80)

Mas além dos escrúpulos dinásticos, presentes tanto em Pedro I quanto em Luís XVIII, que estabeleciam por princípio o da carta "digna de mim", a própria Assembléia Constituinte, convocada no Brasil em 1823, era muito ilustrativa das concepções (não-dinásticas) de cidadania e representação política (que então não se confundiam necessariamente) em voga. Pois para uma pátria recém-criada era necessário definir quem seriam os seus cidadãos.

Contra a idéia de que o título de cidadão cabia unicamente àqueles que gozavam de direitos políticos, o deputado Francisco Montezuma argumentava que todo brasileiro era cidadão brasileiro; convinha apenas que se desse a alguns mais direitos e deveres, distinguindo entre cidadãos ativos e passivos. Em apoio a este argumento, o deputado Nicolau Antônio Vergueiro acrescentava que a lei admitia a igualdade de todos, e portanto todos os membros da sociedade tinham o direito de gozar de todos os direitos políticos, "ainda que o gozo efetivo dependa de outra qualquer condição (...) que pode ser conseguida mais adiante"; evitava-se assim que se formasse uma sociedade composta de cidadãos e não-cidadãos. Mas era o deputado João Severiano Maciel da Costa quem colocava as coisas da maneira mais clara, pois para ele a assembléia poderia usar a palavra cidadão só para aqueles que gozavam de direitos políticos, ou poderia usá-la para todos, distinguindo entre ativos e passivos; o principal parecia não ser que a sociedade se auto-representasse como una ou dividida, homogênea ou heterogênea, pois para além da auto-representação da sociedade estava o princípio básico que ele sabia nortear sua organização:

“(...) sempre haverá diferença de direitos entre os brasileiros, porque nem todos podem gozar dos direitos sociais. Todos os indivíduos que compõem a grande família brasileira têm direito a serem protegidos pela lei no exercício e gozo daqueles direitos para cuja conservação e segurança os homens se uniram em sociedade (liberdade individual, segurança pessoal, direito de propriedade), mas nem todos podem ter o gozo e o exercício dos direitos políticos (eleição, elegibilidade), porque estes decorrem de convenção social e são dependentes de certas condições que não se encontram em todos os indivíduos.” (RODRIGUES, 1974, pp. 122-26)

De um lado a afirmação do princípio da igualdade de todos perante a lei, e de outro o reconhecimento da desigualdade como fundamento mesmo da sociedade política, acabavam definindo a igualdade como um direito, por assim dizer, em potencial, ou seja, o direito que todos igualmente possuem... de se tornarem iguais. Direito que se efetivaria facilmente, desde que observadas algumas condições - ou, basicamente, a propriedade. A desigualdade era apreendida das circunstâncias reais das vidas dos homens, e só uma legislação descolada das condições concretas da sociedade poderia estabelecer uma igualdade absoluta, como notava o conselheiro Pimenta Bueno:

"O voto universal reduz sem dúvida os cidadãos a simples cifras, sem atenção às condições da inteligência e da propriedade; estabelece uma igualdade absoluta, apesar da diversidade e mesmo oposição das circunstâncias dos indivíduos." (BUENO, 1978, p. 190)

Alguns anos mais tarde, em 1872, um outro comentador, Francisco Belisário Soares de Souza, chegava a considerar as "exigências da democracia", as quais eram satisfeitas observando-se a instrução e o pagamento de um imposto direto como condição da cidadania, mas de maneira alguma o sufrágio universal, do qual se dizia um "decidido adversário":

"Insciente, inerte, escravizável por natureza nos tempos ordinários, o voto universal é um imenso perigo nas crises sociais ou por ocasião de comoções populares" (SOUZA, 1979, p.36)

Síntese mais feliz deste pensamento, encabeçava o texto de Soares de Souza uma epígrafe de Edouard Laboulaye, extraída da Revue des Deux 
Mondes: "a multidão não é o povo". Creio não ser necessário arrolar outros depoimentos no mesmo sentido, nem é nosso propósito insistir nesta discussão que já se alonga. O que pretendemos é sugerir que a discussão da questão da escravidão e da cidadania no Brasil do século XIX não deve ser enfocada apenas sob o prisma da restrição dos direitos dos escravos, libertos ou seus descendentes; ou mesmo da contradição inerente entre uma sociedade escravista e uma ideologia liberal. Trata-se, pois, de mostrar não as dimensões da exclusão, mas a maneira como se dava a inclusão daqueles que gozavam de direitos que significavam, em última análise, o domínio sobre os excluídos. Seguindo a pista sugerida na frase de Benjamin Constant que serve de epígrafe a estas páginas, trata-se de entender a preservação da escravidão para alguns como a própria condição da cidadania para outros, e buscar entender desta perspectiva aqueles traços no comportamento dos fazendeiros paulistas que já foram entendidos como sinal de atraso ou de apego irracional a uma rotina.

Momento privilegiado para esta discussão, o período compreendido entre a promulgação da Lei do Ventre Livre, em 1871, e a Abolição, em 1888, coloca-nos frente aos embates políticos protagonizados pelos proprietários paulistas através dos debates que acompanhamos na imprensa republicana da cidade de Campinas. Até então preservada na esfera das relações privadas e resguardada pelo artigo 179 da Constituição, que assegurava o direito de propriedade "em toda sua plenitude", a escravidão sofreria em 1871 o primeiro ataque frontal. Não porque esta data sirva para assinalar positivamente o início do desmantelamento do sistema escravista, ou mesmo porque fosse esta a clara intenção da lei, mas simplesmente porque pela primeira vez a intervenção do Estado trazia para o espaço público e legislava sobre o que até então fora uma questão privada.

É claro que já houvera precedentes de uma legislação sobre a libertação de escravos — porém sempre como exceções (MALHEIRO, 1976, p. 98 101). Mas em 1871 a Lei do Ventre Livre veio configurar a intervenção do poder público na relação senhor-escravo como regra, não mais como exceção, institucionalizando o judiciário como instância mediadora entre senhores e escravos. Não estamos nos referindo à libertação do ventre, mas ao dispositivo que regulava a compra da liberdade pelo próprio escravo mediante indenização ao senhor. Se a liberdade do ventre podia significar para os senhores uma expropriação, um atentado contra os direitos de propriedade, o dispositivo das alforrias forçadas não atrairia menos oposição, visto que não era um único golpe contra os direitos senhoriais, mas introduzia de maneira permanente um elemento subversivo na relação senhor-escravo.

Ainda em 1871 encontramos na Gazeta de Campinas a única crítica que se faria à Lei do Ventre Livre pela imprensa, em um editorial escrito por Campos Salles. Para o redator republicano, era claro que a intenção do governo com esta lei era iniciar um processo de emancipação escrava, por meio de um "mal concebido plano de reforma" cujas conseqüências para a lavoura seriam a escassez da oferta de mão-de-obra escrava e o decorrente aumento de seu custo - "desastre", "calamidade pública", "ruína", "catástrofe". É verdade que todos os sombrios agouros do redator tornavam-se menos sinistros quando inscritos dentro de uma proposta mais ampla, de "substituição de braços" para a lavoura, através do incentivo à imigração.

Mas ainda mais que o futuro da lavoura, as investidas mais ferozes de Campos Salles tinham como alvo a própria política imperial, que possibilitava a aprovação de uma lei contra a sólida oposição da "classe agrícola":

"Nunca se viu levantar tão alto a energia do servilismo. O Rei ordenou, o ministro obedeceu, e cumpriu à risca a ordem do augusto amo, embora para isso houvesse de arcar com a opinião do país. (...) quiséramos também que o governo do imperador 
fosse menos inflexível à vontade nacional e afrouxasse a terrível cadeia com que trouxe os intitulados representantes da nação presos à sua caprichosa prepotência e desse-lhes liberdade ao menos para ouvirem os reclamos da opinião. O governo que assim ousa atentar tão violentamente contra as pacíficas manifestações populares, anulando o direito de petição, e excitando por isso mesmo à revolta, deixa de ser um governo legítimo e regular, para se tornar despótico e reacionário. E a vontade do país estava amplamente consubstanciada nos planos traçados pelo Clube da Lavoura e do Comércio." (Gazeta de Campinas, 03/12/71, p. 1)

O Clube a que se referia Campos Salles fora fundado na Corte com cerca de 600 sócios, em maio de 1871, em função principalmente da discussão da Lei do Ventre Livre, que se iniciava no Parlamento. O Clube da Lavoura e do Comércio era apenas um entre vários exemplos do exercício do "direito de petição" que proliferou naquele ano, quando foram enviadas 33 representações à Câmara e 11 ao Senado na esperança de fazer barrar no Parlamento a reforma do elemento servil patrocinada pelo gabinete Rio Branco (Pang, 1980, p.97). Os planos traçados pelo Clube reduziam-se na prática à criação de um fundo de emancipação, eliminando-se tanto o dispositivo das alforrias forçadas quanto a própria liberdade do ventre. Reduzia-se, em suma, a esfera de ação do Estado sobre a escravidão, pois nos planos do Clube da Lavoura (que em sua modesta opinião era a vontade do país), qualquer reforma no regime de trabalho não poderia ser realizada senão pelos próprios senhores de escravos.

E a adesão de Campos Salles às propostas do Clube é sugestiva ainda para explicar a intrigante ausência dos debates sobre a Lei do Ventre Livre nas páginas da Gazeta de Campinas. Pois como explicar que um jornal de oposição ao regime numa importante região agrícola não se manifestasse antes da promulgação de uma lei que depois viria a criticar tão duramente? Afinal, o artigo em que Campos Salles fazia sua crítica ao governo era a primeira notícia da aprovação de tal lei, mais de um mês de- pois! E a própria Câmara Municipal só daria publicidade à lei num edital publicado em 21 de dezembro, em cumprimento a uma circular do governo provincial de 26 de outubro, numa decisão tomada em sessão na qual ficava bastante explícita a oposição que os vereadores de Campinas (e não apenas os republicanos) faziam ao governo no encaminhamento da questão servil:

"A comissão de ofícios foi de parecer, que se respondesse ao presidente da província relativamente à fundação da associação de que fala a Lei de 28 de setembro: - que não encontra no povo disposição para organizar e auxiliar estas associações; mas que a Câmara está bem informada de que os possuidores de escravos deste município tem procedido com toda a humanidade e zelo na criação dos mesmos libertos, de modo a tornar-se dispensável a organização de tais associações. (...) Quanto à circular, que mandou dar publicidade à mesma Lei, foi de parecer que se cumprisse essa determinação." (Gazeta de Campinas, 24/12/71, p. 1)

Assim, ficava claro que os senhores campineiros não estavam dispostos a permitir a intromissão do Estado em seus interesses privados - aí incluída a escravidão, num momento em que o Estado tentava trazê-la à esfera pública, transformando-a na "questão servil". De qualquer modo, o silêncio tagarela dos senhores campineiros não foi um caso isolado, e nem nos autoriza, como já se pretendeu, a ver na pouca repercussão da Lei do Ventre Livre na imprensa, um indício da indiferença dos fazendeiros do Oeste Paulista para com a questão servil (NOGUEIRA, 1954). Seria, provavelmente, um caso similar ao dos proprietários do município fluminense de Piraí, onde alguns dias antes da aprovação da lei, em meados de setembro, a Câmara Municipal, num esforço de última hora, enviava ao Parlamento uma representação alertando aos deputados que o silêncio e a ausência de debates em jornais enquanto a lei era discutida não deveria ser entendido como "silêncio de aprovação" por parte dos fazendeiros: "a agricultura do país confiou no bom senso dos re- 
presentantes eleitos do povo" (PANG, 1980, p.105). E palavras quase idênticas eram usadas pelo Barão da Paraíba, fazendeiro da Paraíba do Sul e um dos líderes do Clube da Lavoura da Corte, ao explicar a criação do Clube, que vinha desfazer a idéia de que o silêncio dos fazendeiros era um sinal de indiferença política; o que houvera, sim, até então era uma "confiança ilimitada nos poderes do Estado" (PANG, 1980, p.95). Assim, pelo menos neste momento, os interesses de fazendeiros do Oeste campineiro e do Vale do Paraíba convergiam para um mesmo ponto - a garantia de sua participação efetiva no sistema político do Império e, por meio dela, a defesa da propriedade escrava.

As nefastas previsões de Campos Salles quanto às consequiências da lei do Ventre Livre pareciam (ao menos para ele) estar se tornando realidade quando, passado pouco mais de um ano, os vereadores campineiros se agitavam devido à "reprodução freqüente dos delitos cometidos por escravos". Numa sessão em que se discutia o envio de uma representação ao Governo sobre este assunto, o vereador republicano mais uma vez lembraria os esforços seus e de todo o país - para impedir a causa dos males que então experimentavam:

"Lembra que na capital do império formou-se a grande associação do comércio e da lavoura, que tinha por fim obstar a passagem do projeto tal qual fora confeccionado, por ser inconveniente a todos os interesses do país. Nessa associação estavam representados todos os matizes políticos; só lá não apareciam os homens do partido áulico. No mesmo sentido as províncias dirigiram enérgicas representações ao corpo legislativo, e o mesmo fez o município de Campinas." (Gazeta de Campinas, 23/02/73, p. 1)

Assim, os interesses da lavoura eram os interesses do país, desconhecendo diferenças regionais ou partidárias, e só a coroa, ou o "partido áulico", fazia frente a estes legítimos interesses. Pelo menos há que se dar razão a Campos Salles em um ponto: em certa medida os "interesses da lavoura" conse- guiam sobrepor-se aos matizes políticos, de uma tal maneira que pode-se encontrar discurso muito semelhante ao deste representante republicano numa folha conservadora como $O$ Constitucional, que viria a circular em Campinas no ano seguinte.

As semelhanças se encontravam, por exemplo, na identificação da lei de 28 de setembro como um ônus à lavoura, "trazida para o país sem as cautelosas providências que a felicidade nacional reclama" (O Constitucional, 12/06/75, p. 1), e agravando assim a escassez de mão-de-obra quando cessava sua fonte, "fonte ímpia, é verdade, mas ainda assim com pesar o dizemos - a única que até hoje tem mantido a lavoura brasileira" (O Constitucional, 16/ 06/75, p. 1). Mas também (e isso é o mais significativo em se tratando de um jornal conservador) nas críticas ao governo imperial, de quem se esperava uma solução para a crise da lavoura:

"O governo no nosso país só trata de questões políticas, só cuida em promover os meios de segurar-se no poder, e de garantir aos seus sustentadores uma boa posição. A lavoura que é, desculpe-se-nos a expressão, a vaca gorda do Estado, só goza de um favor - que é o esquecimento - com que o governo a trata, lembrando-se de tirá-la deste doce sossego só quando é preciso acordála para sugar-lhe a seiva e exigir-lhe impostos. Fora disto, nem sabe talvez que haja agricultura que definha e fenece por falta de proteção e de amparo." (O Constitucional, 18/07/74, p. 1)

O que a classe dos lavradores reclamava, na verdade, era uma maior participação do poder político, proporcional a sua importância econômica, já que é ela que "quase só, carrega com todos os impostos com que se sustenta a administração pública (...) e todas as necessidades do Estado". Mas a este seu reconhecimento enquanto classe sobrepunha-se, mais uma vez, a identidade entre a classe e a própria nação:

"pois que a classe dos lavradores, compreendendo-se nela os proprietários e seus prepostos, e todos os braços livres ou escravos nela empregados, conta em seu número mais de dois ter- 
ços da população do Império, com as colônias, colonos e agregados (...) É procedendo assim que o governo e o poder legislativo satisfarão seus deveres e darão fiel execução ao mandato que o povo lhes delegou; é só assim que poderão ter o apoio da nação, e conquistar as simpatias, o amor do povo, e as bênçãos da presente geração." (O Constitucional, 18/07/74, p. 1)

A organização da classe da lavoura culminaria em 1876 com a criação do Clube da Lavoura de Campinas, fundado por 45 "fazendeiros" do município, entre os quais se contavam Campos Salles, Francisco Glycério e Jorge Miranda (Gazeta de Campinas, 14/04/76, p. 1), advogados e redatores da Gazeta - se não propriamente lavradores, perfeitamente identificados com seus interesses. Ou que pelo menos assim pretendiam, pois logo ficaria claro a multiplicidade - e às vezes oposição — destes interesses que cabia ao Clube representar.

A fundação do Clube ocorria pouco depois da criação pela assembléia provincial de um imposto de 100\$000 sobre cada escravo comprado de outra província. Em 1878 a assembléia voltava a discutir um imposto sobre importação de escravos, desta vez de 1:000\$000. Neste momento, porém, embora fosse muito maior o imposto, algo fazia supor que a "classe da lavoura" se mostrava dividida, pois a Gazeta publicava em sua sessão particular um artigo assinado pelo pseudônimo de Paulista, com uma veemente defesa do imposto proibitivo:

\footnotetext{
"Sabem os fazendeiros o que quer dizer esse imposto de um conto de réis? TUTELA E SALVAÇÃO. (...) enquanto a imprensa e alguns raros fazendeiros aconselham a colonização, a maioria destes, surda aos reclamos do próprio interesse, responde: mais escravos ! Entretanto não refletem que dia por dia escasseiam os braços escravos; que a maioria dos mais experimentados estadistas asseguram a extinção desse elemento em breves anos; e que desde a lei de 28 de setembro, iniciando a emancipação, a lavoura entrou em uma fase crítica, e reclama as mais sérias providências para conjurar a crise medonha de que pode amanhã ser vítima a principal indústria do país.” ( $G a-$ zeta de Campinas, 17/03/78, p.1)
}

E a única maneira que este Paulista via para conjurar a tal crise seria o início da substituição gradual dos escravos por colonos, o que presumia-se que seria incentivado ao dificultar-se a entrada de escravos na província. Mas outros colaboradores viriam às páginas do mesmo jornal em nome da classe da lavoura para negar que a salvação da agricultura da província dependesse do fim do tráfico interprovincial de escravos. Mais que isso, a classe da lavoura não podia admitir que seus interesses fossem melhor representados pela tutela do Estado:

"Não nos faremos cargo de demonstrar a inconveniência da intervenção do governo nas relações econômicas; o sistema protecionista está julgado, há muito, e não há quem impugne a franca liberdade da indústria e do comércio. Em questões de interesses e conveniências, não pode deixar de ser reconhecido supremo árbitro o interesse particular, único capaz de completa solicitude e tenacidade." (Gazeta de Campinas, 03/03/78, p. 3)

Este autor anônimo concordava que a abolição da escravidão, quando ocorresse, provocaria a crise da grande lavoura, e até o fracionamento da grande propriedade; no entanto, mais do que prevenir a crise, a proibição do tráfico poderia apressá-la, ao impedir a aquisição de escravos que podiam ainda ser por algum tempo empregados na "vantajosa consolidação da fortuna particular":

“é tão produtiva a cultura do café nesta província que os lavradores em poucos anos sentem-se compensados dos capitais dispendidos em escravos (...)" (Gazeta de Campinas, 03/ 03/78, p. 3)

No mesmo sentido expressava-se o autor que usava o pseudônimo de $\mathrm{Z}$ em artigo publicado no mesmo dia em que o Clube da Lavoura convocava uma reunião de lavradores para discutir o projeto anti-tráfico. De acordo com Z, também, o projeto feria "os mais comezinhos princípios da escola liberal em ciência econômica, estabelecendo a tutela pública nos interesses privados" (Gazeta de Campi- 
nas, 24/03/78, p. 2). Mas mais que um princípio, o projeto feria na prática um "recurso vital" para os interesses da província, privando-a do abastecimento de mão-de-obra escrava. É claro que esta condenada tutela pública nos interesses privados não se confundia com uma outra esfera de ação, onde se esperava encontrar no Estado, "os favores e facilidades para a introdução de colonos, e as indispensáveis instituições de crédito". Porém, ao contrário de seu colega anônimo, que previa a crise da grande lavoura e o fracionamento da grande propriedade, $\mathrm{Z}$ acenava para outros interesses ligados à preservação do trabalho escravo:

"Em um país de população escrava como o nosso, onde os trabalhadores aptos para os pesados serviços da agricultura estão consideravelmente aquém das atuais exigências desta indústria, reduzir-se os lavradores aos engajamentos de camaradas nacionais, ou colonos estrangeiros, é cavar a ruína da pequena lavoura, pela absoluta impossibilidade de entrar ela em competência com os ricos fazendeiros para a obtenção de braços. O que ficam valendo os pequenos lavradores perante os capitalistas, desde que não possam fazer aquisição de escravos, nos quais, de parte o valor que representam como propriedade, repousa a melhor garantia dos empréstimos pelo enérgico impulso do seu trabalho à formação da fortuna dos devedores ?"

Por fim, $\mathrm{Z}$ encerrava seu artigo com uma profissão de fé na lucratividade do trabalho escravo; pois mesmo supondo (e ele não podia imaginar então que, mais que uma suposição, isto bem podia ser uma previsão) que a transição para o trabalho livre ocorresse num período de dez anos, ainda assim compensava o investimento na escravatura:

"o abalo que então causasse a transição de um para outro regime não seria tanto de recear, pelo estado próspero em que se acharia colocada a riqueza particular, a esse tempo muito mais habilitada do que hoje para assoberbar os males da substituição."
A reunião do Clube enfim realizou-se, com a presença de cerca de 300 lavradores. Destes, porém, muito poucos se identificariam com o tal Paulista que ia à imprensa para defender o imposto. Na verdade, o resultado desta reunião obriga-nos a perguntar se o debate, veiculado pela Gazeta, que aflorava no seio da "classe da lavoura" não seria um debate interno à redação do jornal, já que Campos Salles será o defensor do projeto que Francisco Quirino dos Santos condenará "sem a menor restrição". Ao final, uma resolução de se representar à assembléia provincial "fazendo ver a inconveniência do projeto" foi aprovada tendo apenas dois votos contrários (Diário de Campinas, 27/03/78, p. 2).

A representação aos deputados provinciais foi redigida em termos muito semelhantes à argumentação de $\mathrm{Z}$, ainda que com uma diferença significativa. Se $\mathrm{Z}$ acreditava que a reforma do elemento servil era "uma questão social já vencida e ganha por efeito da lei de 28 de setembro", o Clube argumentava justamente o contrário para justificar seu apego à mão-de-obra escrava:

"Um outro erro de apreciação dos defensores do projeto está na crença de que o elemento servil, por efeito exclusivo da lei de 28 de setembro, aproxima-se muito rapidamente de seu termo final, tendo entrado já num período de agonia: — daí a urgência de obrigar-se os lavradores a se colocarem ao abrigo da violenta transição. Entretanto, a estatística oficial da população escrava do império, prova que o decréscimo anual pela mortalidade e libertações particulares é de 2\% (...)" (Gazeta de Campinas, 28/ 03/1878, p. 3)

A representação porém foi ineficaz, e o projeto foi aprovado pela assembléia. Foi a vez, então, da Câmara Municipal enviar uma representação ao presidente da província, pedindo que não sancionasse a lei aprovada pelos deputados. E de fato desta vez seus esforços teriam mais sucesso, e a lei não foi sancionada. Assim, pois, mesmo que tivesse razão o Paulista ao afirmar que os fazendeiros 
estavam surdos aos seus próprios interesses, há que se reconhecer que em Campinas eles eram coesos em sua surdez, e que tentavam fundá-la sobre cálculos econômicos, bem como nos "princípios da escola liberal".

Esta constatação leva-nos a uma conclusão bem diversa daqueles trabalhos que pressupõem uma oposição formal liberalismo/escravidão, e que não conseguem por isto dar conta da convivência de relações paternalistas com discursos liberais. Ainda que fosse esta uma demonstração do desenraizamento das idéias liberais no patriarcal império brasileiro, não seria de qualquer maneira uma peculiaridade sua, pois também na Europa os estudos sobre a representação política no século XIX têm apontado que "como em outros sistemas liberais, o igualitarismo individualista devia conjugar-se com identidades coletivas, com estruturas sociais e mentalidades de tipo paternalista-organicista, que de fato regulavam a realidade das relações sociais do país"

\section{Bibliografia}

ARBLASTER, Anthony. The Rise and Decline of Western Liberalism. Oxford, Basil Blackwell Publishers, 1985.

BASTIAT, F. Armonie Economiche. Torino, UTET, 1954

BENTHAM, Jeremy. Tratado de los Sofismas Políticos. Rosário, Editorial Rosário, 1944.

BIAGINI, Eugenio. "I paradossi della Gran Bretagna vittoriana". In Quaderni Storici - Nuova Serie. ${ }^{\circ}$ 69, dicembre 1988.

BOSI, Alfredo. "A Escravidão entre Dois Liberalismos". In Dialética da Colonização. São Paulo, Companhia das Letras, 1992.

BOURNE, J.M. Patronage and Society in Nineteenth Century England. Londres, Edward Arnold, 1986.

BUENO, José Antônio Pimenta. Direito Público Brasileiro e Análise da Constituição do Império. Brasília, Senado Federal, 1978

CUNHA, Manuela Carneiro da. "Sobre os Silêncios da Lei: Lei Costumeira e Lei Positiva na Alforria de Escravos no Brasil do Século XIX". In Antropologia do Brasil: mito, história, etnicidade. São Paulo, Brasiliense, 1987.
(ROMANELLI, 1988, p. 687). Assim, é possível, de uma perspectiva histórica, aproximar a experiência brasileira de outras, a princípio mais facilmente identificáveis ao liberalismo, como a da Inglaterra, onde a presença de elementos tipicamente patriarcais ajuda-nos a pensar a complexidade das políticas liberais no século XIX, ou a própria definição do liberalismo oitocentista (BIAGINI, 1988; BOURNE, 1986; ROBERTS, 1979).

Pelo menos da maneira como entendiam os proprietários campineiros, segundo "os mais comezinhos princípios da escola liberal”, parecia ser perfeitamente razoável esperar pela substituição da mão-de-obra escrava pela livre (transição até desejável) adquirindo mais escravos, enquanto os houvesse. E isto, até quando haveria escravos, parecia ser uma questão de outra ordem, cuja resposta, confiada aos dispositivos da Lei do Ventre Livre, não parecia tão urgente, até que um movimento abolicionista tomou aos fazendeiros a prerrogativa desta discussão.

Negros, Estrangeiros. São Paulo, Brasiliense, 1985.

CARVAlHO, José Murilo de. Teatro de Sombras. São Paulo, Vértice, 1987.

CONSTANT, Benjamin. "Réflexions sur les Constitutions et les Garanties" (1814). Cours de Politique Constitutionnelle., Tome I, Paris, 1872.

Constituições do Brasil. Rio de Janeiro, Editora Aurora, s./d.

COSTA, Emília Viotti da. "Liberalismo e Democracia”. In: Anais de História. Assis, nº 7, 1975.

DAVIS, David Brion. The Problem of Slavery in Western Culture. Harmondsworth, Penguin Books, 1970.

DUVERGER, Maurice. Constitutions et Documents Politiques. Paris, Presses Universitaires de France, 1957.

EVANS, E.J. The Forging of the Modern State: Early Industrial Britain, 1783-1870. Londres, Longman, 1983.

EVANS, E.J. The Great Reform Act of 1832. Londres, Routledge, 1983.

FINLEY, M.I. "Entre a Escravidão e a Liberdade". In: Economia e Sociedade na Grécia Antiga. São Paulo, Martins Fontes, 1989. 
FRANCO, Maria Sylvia de Carvalho. "All the world was America: John Locke, Liberalismo e Propriedade como conceito antropológico". In: Revista USP, n ${ }^{\circ}$ 17, 1993.

HOBSBAWM, Eric. A Era dos Impérios: 1875-1914. Rio de Janeiro, Paz e Terra, 1992.

JARDIN, A. \& Tudesq, A.J. La France des Notables L'Évolution Générale: 1815-1848. Paris, Éditions du Seuil, 1973.

LAROUSSE, Pierre. Grand Dictionnaire Universel du XIX Siècle, tome X. Paris, Administration du Grand Dictionnaire Universel, 1873.

LOCKE, John. Due Trattati sul Governo e Altri Scritti Politici. Torino, UTET, 1982.

MALERBA, Jurandir. Os Brancos da Lei: Liberalismo, Escravidão e Mentalidade Patriarcal no Império do Brasil. Maringá, Editora da Universidade Estadual de Maringá, 1994.

MALHEIRO, Agostinho Marques Perdigão. A Escravidão no Brasil: Ensaio Histórico, Jurídico, Social, vol. 1. Petrópolis, Vozes, 1976.

NOGUEIRA, Emília da Costa. "O Movimento Republicano de Itu: Os Fazendeiros do Oeste Paulista e os Pródromos do Movimento Republicano". In: Revista de História, n 20, 1954.
PANG, Laura J. State and the Agricultural Clubs in Imperial Brazil, 1860-1889. Tese de Doutorado, Vanderbilt University, 1980.

PLINY, Letters and Panegyricus, vol. 1. Londres, Cambridge University Press, 1992.

ROBERTS, David. Paternalism in Early Victorian England. New Brunswick, Rutgers University Press, 1979.

RODRIGUES, J. Honório. A Assembléia Constituinte de 1823. Petrópolis, Vozes, 1974.

ROMANELLI, Raffaele. "Note sull'impianto del sistema elettorale in Italia”. In: Quaderni Storici - Nuova Serie, $\mathrm{n}^{\circ}$ 69, dicembre/1988.

SOUZA, Francisco Belisário Soares de. O Sistema Eleitoral do Império. Brasília, Senado Federal, 1979.

The Institutes of Gaius. Londres, Duckworth, 1988.

THOMPSON, E.P. A Formação da Classe Operária Inglesa. São Paulo, Paz e Terra, 1987.

THOMPSON, E.P. A Miséria da Teoria, ou Um Planetário de Erros. Rio de Janeiro, Zahar, 1981.

WRIGLEY, E.A. \& SCHOFIELD, R.S. The Population History of England, 1541-1871: A Reconstruction. Londres, Cambridge University Press, 1989. 